\title{
Apresentação
}

\section{Mediações, trajetos e ensinamentos: tributo a Jesús Martín-Barbero}

O conjunto de textos a seguir é fruto do colóquio realizado no Programa de PósGraduação em Comunicação da Universidade Federal do Rio Grande do Sul (PPGCOM UFRGS), no final de novembro de 2017, com o objetivo de celebrar os 30 anos de De los medios a las mediaciones. No Brasil, o livro foi publicado em 1997, 10 anos depois da primeira edição em espanhol. Aos textos do colóquio agregamos uma entrevista com Jesús Martin-Barbero, realizada por Maria Patrícia Tellez, e um poema dele gentilmente cedido.

O simples fato de ocorrer essa celebração já indica a importância da obra e do autor para os participantes do evento. Semelhantes encontros foram realizados em muitos países do continente e seu nome está sendo indicado para concorrer ao Prêmio Príncipe das Astúrias, apoiado por muitas instituições latinas e espanholas. Esses encontros, de homenagem e celebração, tiveram início em Cartagena Colômbia na programação do Congresso da International Association for Media and Communication Research, IAMCR 2017, seguiram para Quito e mais tarde vieram para Porto Alegre. Eventos que continuaram em 2018, com tributos realizados na Feira Internacional do Livro de Bogotá, em Barcelona e mais recentemente nas cidades argentinas de Salta, La Plata y Córdoba.

Para o encontro do PPGCOM UFRGS foram convidados 15 pesquisadores, a maioria do Rio Grande do Sul, onde se concentra grande parte dos pesquisadores que trabalham com o pensamento do autor desde sua Pós-Graduação, alguns desde a graduação. Os temas propostos pelos organizadores foram: “Jesús Martin-Barbero e os estudos de comunicação latino-americanos" endereçado aos convidados estrangeiros, "Jesús Martin-Barbero no Brasil: trajetórias, pesquisas e pesquisadores" aos pesquisadores brasileiros da "primeira geração" e "Jesús Martin-Barbero e os desdobramentos da pesquisa brasileira" para os pesquisadores formados pela primeira geração.

Os últimos trataram de suas recentes pesquisas para o doutorado formuladas a partir da obra do autor ou contornada por ela. São os casos dos textos de Daniela Schmitz, que 
tratou da mediação da mídia para entender o desejo de adolescentes de tornarem-se modelos; de Valquiria John que trabalhou com a mediação da telenovela entre mulheres encarceradas para conhecer como se adaptam ao contexto de aprisionamento e se relacionam com o mundo "lá fora" através dela; de Lourdes Silva que extrapolou o contexto da telenovela para entender o melodrama como gênero mediador da trajetória de uma família dedicada à encenação do bumba-meu-boi; de Graziela Bianchi que explora o contexto rural para entender a mediação da relação da pessoas com o rádio; de Ângela Felippi que traz a experiência das pesquisas sobre desenvolvimento regional de seu programa de pós-graduação, as quais adotam o modelo do autor; e de Ronei da Silva, a tese mais recente, que alia a Análise das Redes Sociais ao modelo das mediações para tratar da relação sujeito- internet, na tentativa de aproximar duas tradições.

Monica Pieniz e Liliane Brignol, tendo feito suas teses também com o aporte do autor, apresentam aqui seus avanços em pesquisas posteriores. A primeira para conhecer o processo de reconfiguração da comunicação organizacional na relação com os diferentes públicos, abordando a mediação da tecnicidade. A segunda também destaca a mediação da tecnicidade, à qual agrega a das identidades, ambas como centrais para pesquisas que querem entender transformações do lugar da comunicação e da cultura em contextos de convergência e diversidade.

Se praticamente todos os autores trouxeram um testemunho da importância de JMB para sua pesquisa, Ana Carolina Escosteguy, Veneza Ronsini e Jiani Bonin o fizeram de modo mais enfático, não só porque o tema da mesa assim o sugeria, mas como resultado de uma trajetória acadêmica, cuja filiação ao pensamento do autor se estende ao processo de formação de pós-graduandos, muitas vezes integrantes de grupos de pesquisa como no caso de Jiani.

Fechando a participação brasileira, Maria Immacolata Lopes, que foi orientadora das autoras acima, trata do teor epistemológico e metodológico do "mapa noturno" para estudar as novas complexidades nas relações entre comunicação, cultura e política, analisando os vários mapas metodológicos que têm acompanhado as mudanças das relações estruturais entre comunicação e sociedade.

No que diz respeito aos pesquisadores estrangeiros que participaram do evento, tanto Rosário Sanchez quanto Amparo Marroquim buscam a base de seu pensamento, essa última indo às raízes filosóficas e a primeira ao ambiente teórico e disciplinar da época de sua 
gênesis. Omar Rincón por sua vez, enfatiza em seu ensaio a pregnância de muitas de suas expressões que tornaram-se muito citadas por conter sínteses teóricas de grande efeito.

Queremos compartilhar com os leitores este tributo à obra de Jesús Martín-Barbero, um mestre de quem temos aprendido a olhar o campo da comunicação com outros olhos e outras perspectivas.

Boa leitura!

Porto Alegre / Medellin, setembro de 2018

Nilda Jacks

Universidade Federal do Rio Grande do Sul, Porto Alegre, RS, Brasil

Jorge Iván Bonilla

Universidad EAFIT, Medellin, Antioquia, Colômbia 